$* *$

\title{
Opposing scientific cruelty: the emotions and sensibilities of protestors against experiments on animals
}

\author{
RESUME \\ Après avoir connu un net repli, les mouvements de protestation contre les cruautés de la science à l'égard des \\ animaux connaissent, à partir de la seconde moitié du XXe siècle, une nouvelle phase de développement. Cet \\ article s'applique à montrer dans quelle mesure la prise en compte des émotions et des sensibilités permet de \\ mieux rendre compte des similarités et des différences entre ces mobilisations historiquement distantes. Alors \\ même que les militants de la fin du XX $X^{e}$ réactualisent un registre émotionnel inventé par les précurseurs de la fin \\ $d u X I X^{e}$, la signification qu'ils prêtent à leur révolte est profondément renouvelée du fait des sensibilités qu'ils \\ doivent à des statuts sociaux et expériences affectives fort différents.
}

\section{ABSTRACT}

After a marked decline, protests against cruelty to animals in scientific experiments acquired fresh momentum from the second half of the twentieth century. This article sets out to show that the analysis of emotions and sensibilities is best able to account for the similarities and differences between historically distant mobilisations. While late-twentieth-century militants have refreshed an emotional register invented by their precursors of the previous century, the meaning they attribute to their revolt has been profoundly transformed by sensibilities that derive from a very different social status and a different range of affective experiences.

Christophe Traïni is Professor of Political Science at the Institute of Political Science in Aix-en-Provence. His research focuses on the sociology of activism and collective mobilisation. He is the author of Les braconniers de la République. Les conflits autour des représentations de la Nature et la politique (Paris: PUF, 2003); La musique en colère (Paris: Presses de Sciences Po, 2008), La cause animale (1820-1980). Essai de sociologie historique (Paris: PUF, 2001). He has also edited a volume of essays entitled Emotions... mobilisation! (Paris: Presses de Sciences Po, 2009).

Postal address: Institut d'Etudes politiques, 25 rue Gaston de Saporta, 13625 Aix-en-Provence, cedex 1,. christophe.traini@wanadoo.fr

It is often forgotten that organised protest against cruelty to animals has a long history. At the very beginning of the nineteenth century, protests condemning the ill-treatment of animals by human beings occurred across Europe. At the end of the last third of the nineteenth century, protests focused specifically at vivisection. The constantly ebbing and flowing tide of protest in the following years makes the protests against mistreatment of animals an ideal case to study collective mobilisation over a prolonged period of time. After a marked decline, protests against cruelty to animals in scientific experiments acquired fresh momentum from the second half of the twentieth century. The scope of this article, and the long period the article covers in order to detect similarities and differences, inevitably mean that my descriptions will be exceedingly brief. These protests have always been complex, all the more so in that they are, to an extent, transnational. This article thus makes no claim to being a full account of the complexity; rather it seeks to show how far emotions are essential to an understanding of the evolution of anti-cruelty protests. To achieve this aim we must highlight the importance of analytical distinctions without which it is impossible to grasp the contrasting and complementary affective dimensions that underlie the processes of collective mobilisation. 
The corpus on which my analysis is based is twofold. First, it is based on extensive research in the archives of French societies for the prevention of cruelty to animals in the nineteenth century. This archival research complements a well-developed existing scholarship on similar societies in Great Britain. In particular, I have consulted Bulletins of the Société Protectrice des Animaux (SPA) from 1855 to 1937, and those of the Société Française contre la Vivisection published from 1884 to 1898 , held at the Bibliothèque Nationale de France. Second, I spent several years investigating French militants campaigning against cruelty. This included an ethnographic study, a study of written and other materials produced for the cause, and interviews with a biographical focus. ${ }^{1}$ This twofold corpus has generated some very illuminating comparisons with regard to the historical evolution of relationships between the emotional registers that activists used to focus public concern on animal experiments, and the affective experiences that lead individuals into supporting the cause. In this article, I will attempt to show how far these comparisons highlight the differences among historically separate mobilisations which, at a casual glance, might seem to be mere continuations one of another.

\section{Sociology of mobilisations and emotions}

At one time, emotion was associated with the unscientific nature of crowd psychology and therefore viewed with suspicion. More recently it has become a favourite target for specialists in the analysis of collective mobilisation. ${ }^{2}$ However, this sudden burst of research interest in emotions needs to be tempered by extreme epistemological and methodological caution. To refute the idea that 'emotion' is intangible and hence unworthy of scientific attention, the terms of the analysis must be defined and empirically indexed with the greatest possible precision. It will therefore be illuminating to begin the analysis with a sort of ethnography of the sensitising devices which underlie the mobilisation processes to be examined. By 'sensitising devices' I mean any material supports, dispositions of objects, or staging used by militants to provoke the sort of affective reaction that produces involvement with, or support for, the cause. ${ }^{3}$ These analytical concepts have the advantage of enabling a pragmatic analysis of the objects and conducts militants use to exhibit their own affective reactions and test those of others. In other words, we need to scrutinise the ways in which affective states are inscribed into material objects intended to encourage oneself and others to acts in a way that are deemed appropriate. By appealing to the senses (sight, hearing, touch, smell), sensitising devices are supposed to force the initially indifferent public to react as desired by supporters of the cause. Placing these sensitising devices at the core of the analysis, will thus allow a foregrounding of the materiality and corporality of emotions which cannot be reduced to their discursive dimension. Bodily reactions go far beyond what can be expressed through language, whether before, during or after the action. Unlike a straightforward textual analysis, or a semantics of emotional terminology, the concept of 'sensitising devices' requires an analysis of the material that activists use to incite an affective reaction in bodies that leads to commitment.

The point is thus to treat the expression and testing of emotions as a kind of social praxis. Such practices follow changing norms deriving from types of preliminary socialisation which are more or less common to the contexts under scrutiny. ${ }^{4}$ With regard to the history of 
animal protection, a study of sensitising devices is the key to tracing how successive generations of militants have invented, or reinvented, a range of different emotional registers in order to win public support for their cause. ${ }^{5}$ Before even attempting to explain these twists and turns in the history of animal protection, however, we must draw attention to a number of methodological precautions.

First of all, sensitising devices must be linked to the meanings intended to be conveyed by those who use them. Insofar as they aim to express and arouse emotions, the effectiveness of such devices depends on what William Reddy ${ }^{6}$ calls emotives, i.e. the social conventions which, in a given context, enable the definition, expression, and mutual understanding of affective states such as 'disgust', 'shock', 'hostility', 'benevolence', 'tenderness', etc. Thus an analysis of the way sensitising devices are put to work must adopt a semiological perspective, which is fairly common in the social sciences when it comes to studying how social actors come to terms with the language, codes and grammatical rules of their society. The risk of misinterpretation is small, unless of course the social or historical distance between the subjects and the observer is so great that it encourages misunderstanding or misinterpretation of the meanings the individuals under observation assign to the emotions they express.

While it is essential to make some such an attempt to re-create the perception of emotions by those concerned to express them, it is only part of the overall sociological analysis. The affective states aroused by sensitising devices are never strictly confined to the meaningful intentions and effects anticipated by the users of such devices. In other words, a semiological analysis of the expression of emotions can tell us nothing about what has actually been felt, either by the activists or by the heterogeneous audiences that they succeed in reaching. Even if our enquiry focuses on the defenders of the cause, we must not forget that the relative reflexive control that a person exercises over the more or less spontaneous expression of an emotion leading to commitment to a cause may overlie affective states that are diffuse, complex, equivocal, partly inexpressible, and sometimes incomprehensible even to the person feeling the emotion.

It is easier to understand the importance of analytical distinctions if we refrain from confusing affective states as expressed with affective states as experienced. Reddy was one of the first to point out the need to distinguish between 'emotive' and 'emotion'. ${ }^{7}$ Similarly, the sociologist Deborah B. Gould distinguishes between 'affect' ('an unspecified and unstructured bodily sensation') and 'emotion' ('what is actualized through language or gesture from social convention'). ${ }^{8}$ My approach here is very similar to Reddy's and Gould's insofar as I shall attempt to preserve a clear distinction between what in French would be called émotions, and sentiments. ${ }^{9}$ However, I shall add some further terms by dividing affective states, as experienced, into sentiments and sensibilities. By sentiments I mean the corporeal effects produced by affective reactions arising from a situation, clearly located in time and space, which a sociologist may attempt to re-create from subsequent accounts by witnesses, or by direct ethnographic observation. Sensibilities are more permanent inclinations to react affectively and predictably to objects and situations that are perceived to be similar. In contrast to sociobiologists who tend to postulate a priority of impulses inescapably inscribed into human nature, the notion of sensibility emphasises that the affective states that underlie the conduct of individuals cannot be separated from their social history. In this view, 
sensibilities are like sediments - the accumulated traces that recurring sentiments deposit on a body until they can dictate how it reacts to subsequent events. Since sensibilities are laid down by every experience of the social actors under scrutiny, an observer cannot seek to recreate them without a far greater amount of hypothetical interpretation than would be required for a semiological analysis of the emotions expressed. As we shall see, these distinctions do not refer simply to different dimensions of the object under scrutiny; rather they refer to expressed affective states versus experienced affective states, either in a single situation or repeatedly. The same analytical distinctions emerge from two epistemological systems that have left their mark on the history of the social sciences. The analysis of social behaviours calls for the kind of twofold interpretation that Anthony Giddens calls the 'double hermeneutic'. ${ }^{10}$ On the one hand, scholars have learned from the sociology of understanding inspired by Weber the necessity to understand the meaningful goals of actions performed by social actors. Anthropologists have further taught them that significant interpretative efforts are necessary to understand the world of shared meanings in which the observed individuals live. From this perspective, it is necessary to pay attention to how social actors inform each other, discursively or otherwise, about their affective states. Sociologists thus have to get as close as possible to the life-world of the actors they study. On the other hand, a different branch of social science, notably French sociology from Durkheim to Bourdieu, has taught us that a scientific analysis of social data cannot be reduced to a mere reproduction of the actors' viewpoints. We cannot be content with an understanding of their language and praxis while avoiding secondary analysis based on the specific interpretations and metalanguages that scientists deploy when seeking their own brands of knowledge.

We shall see how an enquiry into the affective states that underlie successive protests against animal experiments highlights this twofold analytical movement. On a preliminary semiological reading, the sensitising devices and emotional registers evoked through these mobilisations seem virtually identical, however widely separated historically. A second reading aims at discovering what makes those sensitising devices work. It is an attempt to explain how far the emotions displayed are a continuation of the (sometimes very heterogeneous) sensibilities both of the militants and of the publics they address. To understand mobilisations and interpret what impels protesters to commit themselves to the cause, it is necessary to assemble a broad variety of often fragmented evidence both on the micro- and macro-level. In other words, the approach here is to do partly an objectivising analysis, partly a genealogical and conjectural endeavour which seeks to reconstitute

processes that cannot be observed except indirectly, through a tangle of clues. ${ }^{11}$ More precisely, I shall attempt to reconstruct socially constructed sensibilities which renew themselves through the emotions that are expressed and evoked by militants.

\section{The emotional registers of an old and multifarious cause}

If we want to understand how the history of animal protection movements has been influenced by changes in the emotional registers preferred by militants, the best way is to look at the evolution of animal protection over the long term. The oldest campaigning organisations developed in Europe from the first half of the nineteenth century, following in the wake of the London activists who, in 1824, founded the Society for the Prevention of Cruelty to Animals. By 1869 Britain had 33 societies of this type, Germany 44, and Austria 
21. France had three, including the Sociéte Protectrice des Animaux, founded in Paris in 1845. The membership of these numerous societies came from the ranks of the clergy, the bourgeoisie and the aristocracy. Throughout the nineteenth century these moral entrepreneurs $^{12}$ strove to mitigate the brutality inflicted by uneducated workers on the animals in their charge. Sermons, exhortations to kindness, rewards for the meritorious, votes in favour of legal definitions of cruelty, punishment of offenders, were the sensitising devices used to support the demopedic emotional register which inspired the first generation of militants. They reacted to brutality with indignation, while feeling a degree of benevolence towards those who acted more out of ignorance than definite cruelty. Carters, coachmen, farm workers and butchers were seen as deviants who could be led back to the right path by the teachings of the protection societies. This comparative benevolence towards deviants, and the gratitude of such deviants towards the benefactors who had re-educated them, were added to the emotions intended to be aroused by sensitising devices so that animal protection could become a live issue among the lower classes.

In comparison with these early animal protection societies, protests against cruelty inflicted on animals by scientists constituted a later wave of specific mobilisiations. ${ }^{13}$ In 1875 , in London, Frances Power Cobbe founded the world's first society pledged to combat animal experiments, the Society for the Protection of Animals Liable to Vivisection. ${ }^{14}$ Just one year later, the Royal Society for the Prevention of Cruelty to Animals (RSPCA), founded in 1824, listed no fewer than ten anti-vivisection organisations in Britain. They set about spreading their cause in European countries, which were sometimes described as missionary territory. Germany and Austria were favourable ground for the anti-vivisection cause - ground which had been prepared by the numerous animal protection societies that had been created in previous decades on the model of the RSPCA. Two similar organisations appeared in France in 1883: the Ligue Populaire contre la Vivisection and the Société Française contre la Vivisection. Hence it is no exaggeration to speak in terms of an international anti-vivisection movement. In 1885 the Bulletin de la Société Française contre la Vivisection listed no fewer than 26 anti-vivisection societies in eight countries: 15 in Britain, 3 in Switzerland, 2 in Germany, 2 in France, 1 each in America, Belgium, Italy and Sweden. ${ }^{15}$ The transnational character of this movement is clear from the promoters' efforts to take their struggle across frontiers. Thus Cobbe's commitment appears to have had a determining influence on the intense public campaign launched in Florence, Italy, against the German physiologist Moritz Schiff. ${ }^{16}$ Similarly, not satisfied with promoting the International Association for the Total Abolition of Vivisection in England, Anna Kingsford travelled all over Europe encouraging the foundation of anti-vivisection societies. The one she created in Geneva attracted severe censure in 1883, in an article by Henri Kleffler whose title pulled no punches. ${ }^{17}$ Perusal of the Bulletin de la Société Française contre la Vivisection shows how extensively denunciations of the practice drew on translations from British pamphlets. They were also translated into German, although German anti-vivisectionists also produced a copious pamphlet literature of their own, some of which, like Ernst von Weber's Torture Chamber of Science, were quickly translated into French and Italian. ${ }^{18}$

The anti-vivisection societies were innovative not only in their aims, but also in their use of sensitising devices to nourish a new kind of emotional register. No longer did they rage at the improper brutality perpetrated in the public space by uneducated and marginal 
people. Rather they exposed the atrocious practices that men who saw themselves as an elite, at the forefront of progress, were engaging in out of public view, hidden in their laboratories. There was no room here for the sort of sermons and promised rewards doled out to repentant offenders. Rather, the anti-vivisectionists abstracted and commented on plates taken from vivisection manuals; they quoted horrified witness accounts from militants who had found their way into laboratories, told edifying tales about children or wives of vivisectionists unexpectedly coming upon animals being ripped apart while still alive, and invited the reader to imagine himself as a cherished dog delivered up to vivisectionists by traffickers. These new sensitising devices formed an emotional register of exposure thrust before the senses and sensibilities of the public. Thus in 1883 Frances Power Cobbe, founder of the Society for the Protection of Animals Liable to Vivisection, published Light in Dark Places. Translated into French the following year, it included a large number of engravings taken straight from physiology textbooks: knives, scalpels, pincers and scissors; devices for holding down dogs or rabbits with a series of incisions in their sides; a frog's nerves attached to a measuring instrument; a machine to produce artificial respiration in guinea pigs, etc. This kind of material encouraged readers to judge the horror of vivisection based on the instinctive reactions aroused by seeing a body violated. In case that was not enough, some sensitising devices sought to stimulate the reader's imagination by encouraging him to place himself as close as possible to the stigmatised practice. Eye-witness reports showed how painful a visit to a laboratory was to a person of ordinary sensibilities: the sight of a 'little poodle, bloody, mutilated, fully conscious and seeming to suffer horribly'; background noises combining into a 'long and agonised moan'; 'cries and screams of pain mingling with the voices of the torturers commanding silence'; and the inappropriate scent of the tobacco being smoked by 'operators cheerfully smoking and chatting'. ${ }^{19}$

\section{Emergence of an emotional register of revelation}

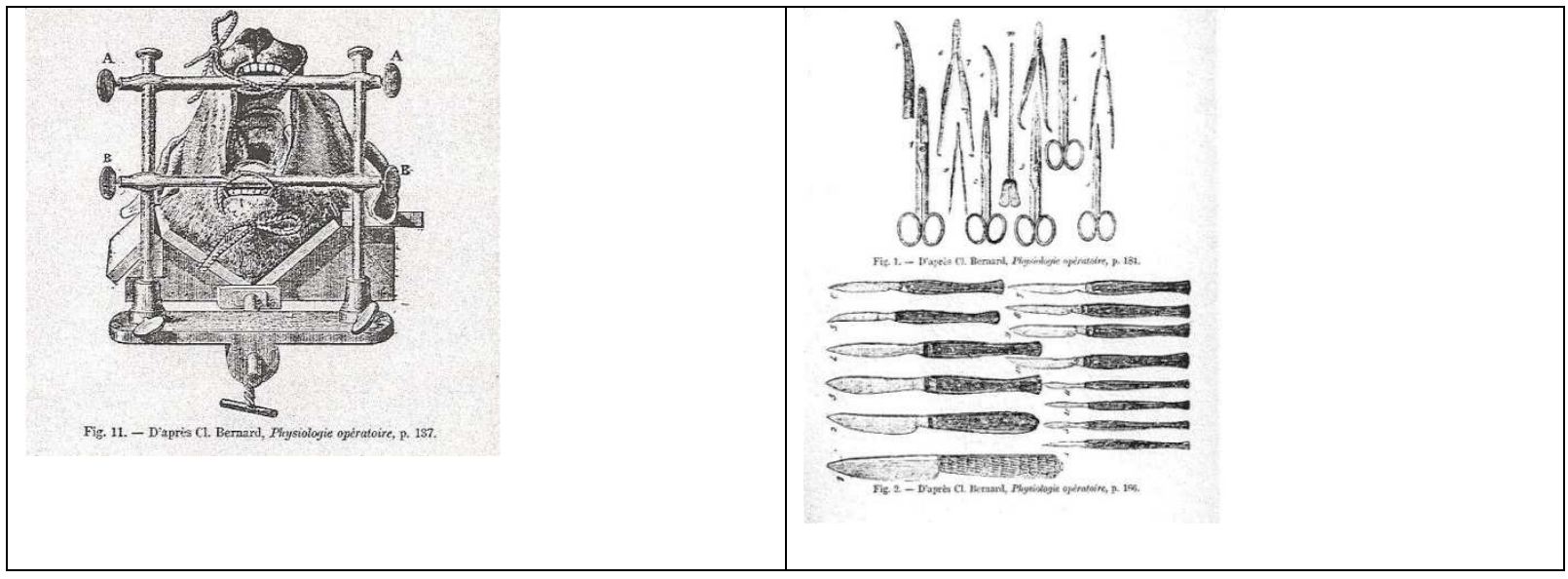




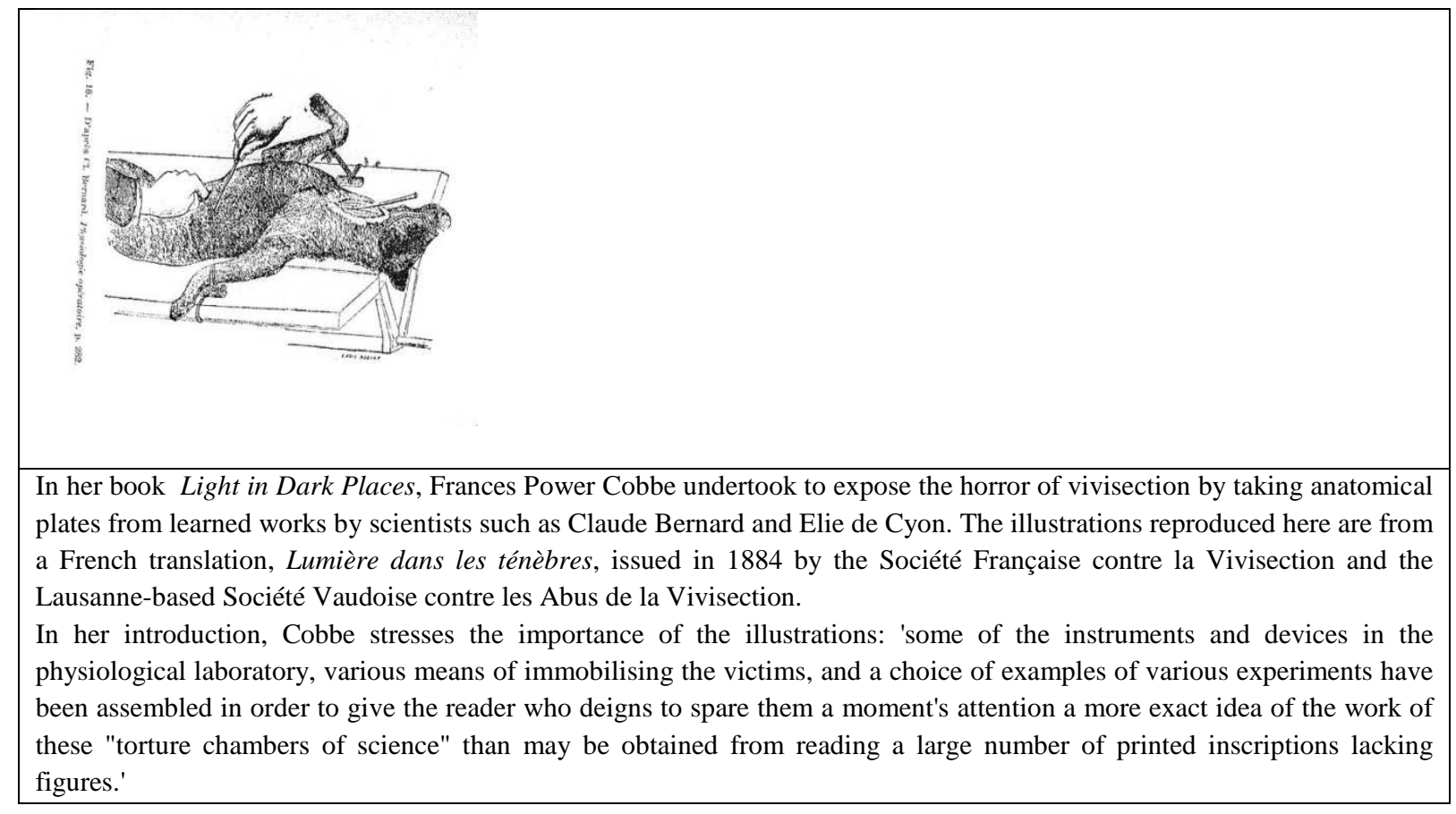

At times, this new-fangled militant material called on sympathisers to imagine themselves as laboratory animals, particularly by likening the latter to human patients who are supposed to be cared for by doctors. In every case, the idea is to arouse suspicion as to the real motives of scientists seeking access to the bodies of men or, worse, women:

much evidence goes to show that these supposed scientists are possessed by an unhealthy curiosity ... a certain Doctor Pélican ... had the abominable idea of performing experiments on spontaneous combustion on women who were chronic alcoholics. While they were unconscious from drink, he would administer as much alcohol as they were capable of absorbing; this done, he would approach with a lighted match to their mouths ... Similarly, at every instant, in the Salpêtrière, the most immoral and scandalous experiments are conducted on the phenomena of hypnotism and suggestion ... Neither the sex nor the free will of the subject are respected. Flesh is scratched, pinched, stabbed, cut. When the patient regains consciousness and sees the bloody traces on his body, he cannot protest. $^{20}$

Like detectives - which crime novelists celebrated at about the same time - antivivisectionists pursued the criminals wherever they tried to conceal their crimes. They showed no mercy for these monsters in the shape of men! The aim was to arouse emotions leading to a desire to put an immediate end to the intolerable suffering being inflicted on defenceless animals. Shock, disgust, pity for the victims immobilised on the table, anger and a thirst for vengeance on the cold-blooded torturers: all in all, the emotions expressed, and solicited from the public, justified action, even violence, to put an immediate end to a practice so horrible that it could claim no possible legitimacy. 


\section{Emotions and social anchorage of precursors of the Cause}

It would be very reductive to attribute all the effectiveness of sensitising devices to the ingenuity of the militants who used them, and their expertise in techniques of communication. Sensitising devices cannot affect the public unless they actualise and prolong pre-existing sensibilities arising from social experiences, which may be identified by an indexing analysis. Towards the end of the nineteenth century, protests against scientific cruelty cannot be dissociated from competition between forms of authority - those in decline and those in the ascendant. In the following century, the militants who carried on the cause were responding rather to a day-to-day confrontation with impersonal technocratic logic.

From the end of the nineteenth century, indignation against vivisection sprang from a sentiment of hostility among traditional elites - old aristocratic families, clergy, and judiciary - which had produced the individuals who began the protest movement, particularly in countries like Britain, Germany and Austria. Among these old elites, repugnance at vivisection was a prolongation of the mingled hostility and anxiety inspired by the rise of an empowered bourgeoisie that was monopolising science in order to exploit a new source of authority. The prestige associated with scientific experiments was a challenge to the prestige that previously came with distinguished names, rank, or membership of a noble family acknowledged by the highest echelons of society. ${ }^{21}$ This increasing competition between different forms of authority is also apparent from denunciations of scientific arrivisme. Frances Power Cobbe was particularly prone to describe doctors as 'a class of parvenus, caring nothing for patience or compassion, motivated more by the desire for gain and the advancement of science than a desire to improve the condition of their fellow men'. ${ }^{22}$ Speaking in France in 1885, Maria Deraismes similarly declared that the practice of vivisection arose mainly from an unbridled desire for social advancement: 'Torture and horrible sufferings count for nothing. Scientists are not men of the world [Desraismes's emphasis].' Claude Bernard wrote:

If I had to furnish a comparison to explain my feelings about the science of life, I would say that it is a splendid hall, full of light, but which cannot be reached without passing through a long and horrible kitchen. We can certainly see the long and horrible kitchen; kindly now show us something of the splendid hall, even if only through a half-open door.[ ...] The desire to attach one's name to an alleged discovery and the no less intense desire to profit from it are the sole motives of this rage for experiment. ${ }^{23}$

This struggle between those climbing and those descending the social ladder was sometimes accompanied by anxiety arising from the devaluing of an older system for the transmission of knowledge: "The "spirit of scientific inquiry" was driving out of the schools "the old and long-established ideals of collegiate training" and destroying the willingness of students "to accept facts upon others' testimony", ${ }^{24}$ This encouraged another kind of public to join the anti-vivisectionists: doctors and physicians too old to profit from recent developments in experimental method. Some of these older doctors found the indeterminate discoveries of the vivisectionists all the more repugnant in that these young scientists rejected the knowledge that their elders had painfully acquired through long years of clinical 
observation as obsolete. Rising appreciation of the experimental method was all the more worrying in that it reduced doctors from persons of importance in their own neighbourhood to anonymous dependents of the laboratories.

As time progressed, however, the majority of anti-vivisectionists seem to have been marked by a quite different set of social and affective experiences: the militant wing of the movement was becoming noticeably feminised. Numerous bourgeois women who devoted their time to running dogs' homes were enthusiastic anti-vivisectionists, particularly as there were many rumours to the effect that laboratories were using unfortunate pets that had momentarily strayed away from their owners. Thus the Société Française contre la Vivisection used the distress of losing a pet as a powerful sensitising device to foster commitment to the cause. ${ }^{25}$ However, this feminisation was not due solely to the fact that protecting dogs was one of the few ways available to women of being active in the public space without betraying the vocation of protecting the weak which was assigned to them in the private sphere. The emotions aroused by anti-vivisectionists' sensitising devices also awoke fears and unpleasant feelings arising from incompatible social trends. On the one hand, this fin-de-siècle was the apogee of prudishness. On the other, women were encountering the beginnings of gynaecology - a medical domain run by men but centring on the reproductive function of women's bodies. In those circumstances vivisection seemed all the more horrible in that certain analogies could be perceived between the fate of the animal and that of a woman being scrutinised by a medical practice that might seem to be animated by unhealthy and intrusive curiosity. ${ }^{26}$ It must be admitted that this inference - that women at the turn of the century were particularly sensitive - can only be inferred from a set of clues pointing to the kind of second-order interpretation mentioned earlier, with the accompanying interpretive risk. ${ }^{27}$ What are these clues? For example, a leading figure in the movement, Anna Kingsford, was one of the first Englishwomen to gain a medical degree and start a medical practice, which was enthusiastically patronised by women happy to find that they would not have to be examined by a man. In France, similarly, the Ligue Populaire contre la Vivisection was founded in 1883 by Marie Huot, inventor of the 'womb strike' slogan which was one of the first public assertions of women's right to control their own bodies.

Despite these very promising beginnings, anti-vivisection protests soon went into a marked and rapid decline. The successes of experimental science and the spectacular advances which it afforded to medicine had effectively silenced the few scientists who still doubted its utility. Moreover, the response to the anti-vivisection campaign in English legislation, particularly in 1876, triggered a counter-movement among physiologists. In 1882 British scientists founded the Association for the Advancement of Medicine by Research and launched a violent campaign against their detractors. Their strategy was to discredit antivivisectionist criticism by attributing it to an excessive sensibility typical of women. The argument was the more credible in that the anti-vivisection movement had indeed been heavily supported by the bourgeois women who, at the time, were creating the earliest dogs' homes. This feminisation of the anti-vivisection movement was a convenient starting point for counter-moves by scientists, who used both scientific and sexist arguments to discredit their opponents. ${ }^{28}$ In 1884 the French psychiatrist Valentin Magnan explained anti-vivisectionism and other, more general and dubious feelings towards animals on the part of certain women, 
to a kind of hereditary insanity. ${ }^{29}$ Thus anti-vivisectionism was methodically undermined, with results that lasted into the second half of the twentieth century. And for many decades there was no sign of a resurgence in protests, not only against the sufferings of laboratory animals but also against the legitimacy of scientific experimentation itself.

\section{Advances in communications technology and reactivation of the emotional register of exposure}

More than a century later, in the late 1970s, a new generation of militants took over not only the theme of scientific cruelty to animals, but also the emotional register of exposure. In this context the advances in information and communication technology cannot be ignored. Communication technology, in particular, made it possible to appeal far more directly to the senses than could be done through the reports and anatomical plates used by earlier militants. It was now possible to expose the horrors lurking behind laboratory doors by using photographs - and colour photographs at that - which notably extended the potential for disgust and shock: pictures of tattered bodies, terrified animals crouching at the back of their cages, bodies being mutilated by instruments, etc. Audiovisual recording was even better suited to developing the emotional register of exposure. The Animal Liberation Front (ALF), founded in Britain in 1976, adopted a kind of action that was doubly unprecedented. Its young militants not only infiltrated laboratories so as to free animals destined for scientific experiments, but also made films to show the public the intolerable conditions being imposed on guinea pigs. These videos were far more effective, as sensitising devices, than the appeals to the imagination of nineteenth-century readers; they did a great deal to bring

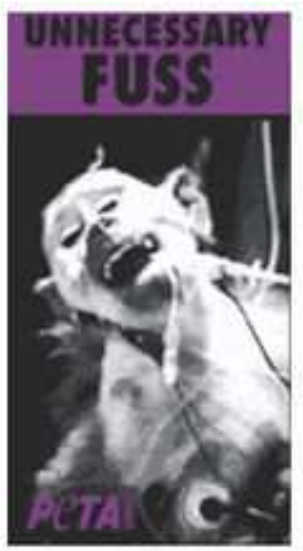
new adherents to the cause. In 1984, as part of their campaign against the University of Pennsylvania, ALF militants took some horrific pictures of experiments on baboons. These pictures were used by People for the Ethical Treatment of Animals (PETA) in the film Unnecessary Fuss, which paved the way for numerous audio-visual sensitising devices used subsequently by opponents of animal experimentation. Technical progress extended the repertoire to include multiple visual and sound elements which acted together to intensify the shock effect: pictures of experiments on monkeys; the noise of machines and tools in use; experimenters talking among themselves; voice-overs by a PETA militant; accusing texts at the beginning and end of the film. In the following decades, films uploaded to the Internet by anti-experimentalists made much more sophisticated use of audio-visual montage than was seen in Unnecessary Fuss.

The PETA, founded in 1980 in the USA, can be seen as the prototype of a new generation of associations in the USA and Europe which assumed a much more confrontational and radical stance. (This, of course, was inseparable from their heavy reliance on the emotional register of exposure.) This new radicalism surely owed a great deal to moral 
philosophers such as Peter Singer and Tom Regan. ${ }^{30}$ It cannot, however, be considered in isolation from the resources for the dissemination of sensitising devices that were now available to those anxious to reveal the hidden violence being visited on innocent animals. Audio-visual communication enabled the opponents of animal experiments to find support more easily beyond the closed, educated circles to which cyclostyled pamphlets had previously been confined. The dissemination of photos and films too horrible - and controversial - for publication in traditional media successfully aroused the sort of intense emotions that were likely to rally a potentially much larger audience to the cause.

There are several indications that anti-experiment protests revived in the last quarter of the twentieth century. First, the increasing international dissemination of modes of action advocated by the Animal Liberation Front, which liberally exploited the new channels of distribution offered by audio-visual media and subsequently, from the late 1990s onwards, by the Internet. In just one year, 2010, ALF's website recorded 369 illegal operations against laboratories and farms in no fewer than thirty countries. In the vanguard were Sweden (68 operations, Italy (50), Germany (46), the USA (43) and Mexico (40); France came ninth with 13 operations. ${ }^{31}$ Another indicator of the diffusion and intensification of opposition to animal experiments is the creation of new associations protesting against the treatment of laboratory guinea pigs. In France alone, the 1990s saw the creation of several associations which listed protests against animal experiments among their priorities. They included the journal Cahiers antispécistes. Réflexion et action pour l'égalité animale (1991); Pro-Anima, a scientific committee (1994); the association One Voice: Pour une Ethique Animale et Planétaire (1995); the association Droit des Animaux (2002); and the Collectif Libération Animale de Montpellier (2005). Not only these new associations, but also big organisations dedicated to animal protection in general latched on to the theme. In 1991 Samir Mejri's book Victimes silencieuses. Deux années dans un laboratoire d'expérimentation animale was published with the support of the Fondation Brigitte Bardot (set up in 1986). The book, narrated by a young man who chanced to get a job as an animal technician in a laboratory, purported to expose the horrible details of what went on in a medicines production unit. Written as an eye-witness account of a sojourn among horrors, and aimed at a wide public, this militant publication is a remarkable illustration of the approach to the expression and testing of emotion that is characteristic of the register of exposure. ${ }^{32}$

\section{Social anchorages and reawakened sensibilities}

We have shown that a semiological analysis of sensitising devices makes it possible to detect not only the continuity of the emotional register of exposure, but also its adaptability to advances in communications technology. However, our chosen approach cautions that we should not be satisfied with merely noting an apparent continuity of indignation, fostered by successive generations of militants. In fact, the protests against scientific cruelty that developed in the second half of the twentieth century rested on a social anchorage and a range of sensibilities quite different from those of the late nineteenth century. The social positioning of the militants who contributed to the resurgence of protests against scientific cruelty was clearly different from that of the old elites - doctors clinging to their clinical knowledge or bourgeois women confined to the private sphere - who had spearheaded the mobilisations of the previous century. From the 1970s onwards, most activists seem to have emerged from an 
ever more highly educated middle class. Ronnie Lee, founder of the ALF, was a law student, originally a member of the Hunt Saboteurs Association (HSA) that was set up in 1962 to hamper the quintessentially aristocratic practice of foxhunting. Our own recent study of French animal protection militants shows that protests against animal experiments are commonly conducted by middle-class, comparatively well-educated young people. Obviously our qualitative approach, coupled with the inevitably limited number of interviewees, makes it impossible to treat this characteristic as an objective statistic. However, even such scattered and fragmented clues show a clear enough set of contrasts with the previous century - enough to support the idea that a change had taken place in the social anchorage of the sort of sensibilities that generate protest against scientific abuses. Moreover, the new profiles of persons committed to the cause make it possible to discuss both the relevance and the limits of Hans-Peter Kriesi's general arguments relating to the new social cleavages which underlay mobilisations during the second half of the twentieth century. ${ }^{33}$

Kriesi, a specialist in social movement studies, argues that changes in post-industrial society generated a new social gulf between groups with the means to exercise control, and groups without them. This, he argues, meant that social conflict shifted to the new middle class which had emerged after the Second World War between the bourgeoisie and the working class. As a result, many social movements are now sustained not by the middle class as a whole, but by a specific category of 'socio-cultural specialists'. Though highly educated, they are not in a position to use their skills to control the functioning of the organisations, public or private, for which they work (mostly in teaching, the arts, journalism, social work or the health services). Unlike technocrats and managers, socio-cultural specialists organised in order to demand greater empowerment - more control - not only in the workplace but in society generally. Many emerging movements, particularly in the 1970s, were inextricably linked to this ever-growing question of autonomy and control over the circumstances of existence: the anti-nuclear lobby, political ecology, regional autonomy, gay rights, women's rights, revival of regional languages, etc. While Kriesi's hypothesis may seem very general, it provides new insights in the transformation of the social and affective substrate of protests against animal experiments. In the first place, the social and professional origins of the militants, where they can be determined, seem to fit the category of 'socio-cultural specialist' quite neatly: doctors rejecting the industrialisation of their profession; artists who have shared a squat with autonomists; professionals unable to find a job commensurate with their university degrees; and, above all, secondary school teachers.

It will be readily understood that Kriesi's hypothesis assumes that the middle classes harbour a recurring sentiment of a deficit in autonomy and control, and that this sentiment nourishes a particular kind of sensibility, quite unlike that which inspired the aristocratic or bourgeois anti-vivisectionists of the preceding century. Indignation directed against animal experiments could be seen to extend beyond the animal victim, extending and formalising the feeling of being oneself the victim of a cold and inhuman technocracy which treated individuals as anonymous, interchangeable cogs. Commitment to opposing animal experiments, the expression of emotions aroused by the sufferings of laboratory animals, can thus be seen as a way of taking feelings aroused by social experience, in a society that seemed to allow very little autonomy to highly skilled individuals, and transmuting them into a principled basis for activism. This helps to explain why sensitising devices were now often 
used to compare the sufferings of animals and those of humans, equally subject to technocratic apparatus or technocratic thinking that prevented them from being masters of their fates. In 1985 a pamphlet issued by the Ligue Française contre la Vivisection, entitled Tortures sans frontière. Torture des hommes, torture des animaux, l'expérimentation sur les animaux, claimed indignantly that animal experiments were a form of torture: 'torture is the crushing weight of a will to inflict suffering and death on creatures - human or animal confined in a space where no resistance is possible.' ${ }^{34}$ Another of the Ligue's pamphlets, Les transplantations en question, accentuates the horror of bodies being manipulated like coarse raw materials by showing photographs of mutilated dogs - and of Paraguayan babies allegedly sold to stock organ banks: 'We started by massacring animals, we end by massacring babies [...] In this world of machinery and electronics, where mechanics have crushed the ethical and aesthetic side of life, it is a vast and disappointing endeavour to try to arouse consciences that are drifting towards an uncertain horizon. 35

Obviously the tragic history of twentieth-century warfare is another source of inspiration for this parallel between animal and human victims of experimental science. As we saw earlier, this kind of comparison had featured in the writings of anti-vivisectionists in the previous century. But its shock value was considerably intensified once it was possible to evoke the industrial organisation of Nazi concentration camps. In one of the Ligue pamphlets cited above, there is a photograph of a building with a high chimney, bearing the caption: 'Cremation oven of the experimental surgery laboratory of the Salvator Hospital, Marseilles. How many dogs have gone up in smoke through this chimney? If Science and Technology must advance through the smoke from cremation ovens, the destiny of mankind will go up in the same smoke, as they are incinerated by the technology and science of nuclear, chemical and germ warfare.' Similarly, in Animal Liberation (1975), often seen as the basic textbook of generations of ultra-radical militants, Peter Singer quotes the Jewish author Isaac Bashevis Singer who had claimed that 'in their behaviour towards creatures, all men are Nazis. ${ }^{36}$ Several decades later, the same argument is still heard from militants protesting against both animal experiments and meat-eating. As Kriesi's hypothesis would predict, since the 1990s the most radical wing of the animal protection movement has completely equated scientific cruelty with factory farming, accusing both of reducing animals to raw material to be processed along Taylorian lines. Indeed, militants express the same anger at blind cruelty to animals as at the way technocratic societies crush human freedom of choice and the spirit of revolt.

For me, at least ... The picture really shows how people were treated in concentration camps. What I mean is ... I think that what we do to animals is the same. I really do see it like that. Yeah, I read the book ... Afterwards, well, that wasn't why I became a vegetalian ... But I had that book by Charles Patterson, Eternal Treblinka... and he's right ... The way he links it with Nazism .. I think humans behave like Nazis towards animals ... When I think about that, I just can't go on like I did before ... Because I feel you can't pretend it isn't happening ... go on as normal. ${ }^{37}$

Somebody who eats meat, they aren't actually the murderer. They delegate that to someone else who does it ... Somebody who just happens to work in an abattoir. After that it's easy to make the parallel ... Before, in Germany ... in Asia etc. Any time when there was totalitarianism. ${ }^{38}$ 
This unprecedented convergence of protests against, on the one hand, the abuses of science, and on the other, the way humans treat animals doomed to the butcher's hook, is a very significant clue in itself. It would have been inconceivable to the nineteenth-century antivivisectionists $;{ }^{39}$ it confirms the crucial importance of the desire to take control of one's own existence. Militants opposed to scientific cruelty now often adopt severe, sometimes very severe, dietary restrictions. While vegetarians simply refuse to eat meat, vegans also refuse to eat any the products of any other kind of animal exploitation: eggs, milk, cheese, honey, etc. Some of them even go so far as to boycott things like silk, wool and leather. These militant practices, which require hard effort and self-discipline, are a good way to test and consolidate the intensity of one's commitment to protest. ${ }^{40}$ In particular, they give animal protection militants a sphere within which they can be autonomous, where they can pursue their eating habits without reference to the economics of markets dominated by the technical and commercial preferences of big companies. Their desire for autonomy emerges clearly through a cause which, at one and the same time, combats the horrible fate not only of guinea pigs and farm animals, but also of citizens reduced to the status of passive and constrained consumers.

\section{Affective experiences, sensibilities and commitment to the cause}

As we have just seen, Kriesi's hypothesis seems capable of explaining the growing expression of a desire for autonomy among people whose social status condemns them to a high degree of dependence. It is, however, too general to explain all the variables leading to commitment to the cause. Many sociologists specialising in mobilisations have stressed the limitations of approaches which assume that commitment follows mechanically from certain social positionings. ${ }^{41}$ Such positionings can do no more than predispose individuals to commitment. The predisposition may never lead to anything unless it is brought to the surface, a process to which sensitising devices make an important contribution. While it may be true that most opponents of animal experiments are socio-cultural specialists, it must be remembered that the majority of such specialists have never been exhorted to commit to the cause of animal protection. If we are to account for the processes that lead some of them - rather than others to find satisfaction in the emotions aroused by the register of revelation, other avenues of enquiry will be required. This means that interviews with militants are invaluable. Through them we can detect certain types of social experiences which lie behind the sensibilities which militants owe to their socialisation in the family or in school, or to turning points in their early lives which left a stamp on their affective memory, often before they reached the age or professional status that would identify them as socio-cultural specialists. First and foremost, all animal protection militants stress the importance of special affective relationships with their pets, usually cats or dogs, beginning at a very early age. Other, more or less idiosyncratic affective experiences are reported by militants who belong to organisations which attach importance to the emotional register of exposure. Rejection of animal experiments often seems to be a prolongation of inclinations which the militants concerned developed as a result of experiencing vulnerability in situations that led them to identify with defenceless animals. The interviews reveal the diversity of these experiences, most of which go back to childhood: witnessing the killing of a rabbit they were fond of; disgust at a classmate who enjoyed cutting up insects or stoning birds; unjustified violence visited on them by their own parents, 
etc. As an example, here is a significant case involving strong identification with a laboratory guinea pig on the part of a militant with Agir Contre la Torture des Animaux (ACTA) :

In my personal life, there was a particular moment when I told myself I was going to be a vegetarian ... um ... I don't often talk about it [embarrassed] .. But I think there is a connection! After all [nervous titter] Well, broadly speaking ... I don't know how to say it. When I was 17, I got pregnant and had an abortion [...] It was really horrible ... And it strengthened my feminist convictions ... How they received me at the hospital, the information etc. And I found out that at that time, the pills they gave me ... RU 486, it's usually given to cause premature abortion ... They gave it me to dilate the cervix. And I happened to be looking on the Internet and found out that it was actually undergoing clinical trials at that time! They never told me! When they made me take it!! So I just bled white ... It was horrible! And from then onwards, I short of felt there was all kinds of violence being done to me ... Hurting me, like being driven to the slaughterhouse! And that day, I said to myself, 'That's enough!' That's what made my mind up for me, in the two years when I was moving towards being a vegetarian ... I would say 'Now I'm eating no more meat, I'm going to reconnect with myself!' [...] It all sort of came together ... And I said to myself, there has to be a way of getting a grip on your own life. You grow up, you stop putting up with what other people decide is best for you $!^{42}$

It must be stressed that this identification with vulnerable, unjustly persecuted creatures was only the first stage in a much more gratifying affective reaction, that of rebelling against people who bully those weaker than themselves. This becomes even clearer if we listen to another militant who, in 2007, founded the Coalition Anti Vivisection. Here she is remembering how she first felt the need to do justice by protecting the most vulnerable creatures:

I think I was sensitive when I was very little ... really very little ... And I was always debating with myself about it ... Why is this...? I always felt respect for animals! Even ants! I remember once going to a holiday camp, children injecting .. Kicking an anthill to see how they'd react .. I was already going ..'Hey, stop! Leave them alone! You wouldn't like it if somebody did that to you ... Leave them be!' And the ones who pulled the heads off grasshoppers or the legs off spiders ... I just hated that! 'Just leave them alone! It's too easy to do things like that to insects!' Children in the playground .. It was when I was in middle school... Even before that, I remember ... I always tried to defend the weak. Anyway I was really in the same situation as the weak ones, myself ... Because I was friends with 'Nit-head' and 'Fatty' ... All the rejects at the bottom of the barrel ... I became sort of the protector ... I mean that in the playground, I didn't mind thumping the big kids who bullied the little ones [...] I think unfortunately I'm too prone to put myself in other people's shoes ... Including animals these days ... And yes I think there are quite a lot of militants who put themselves in the place of animals. ${ }^{43}$

This sort of statement confirms what is known about Ronnie Lee, who founded the Animal Liberation Front in 1976. In an interview kept at the British Library, Lee similarly links his determination to combat scientific abuse with a highly significant affective experience of his own. Ronnie, an undersized child, was constantly being tormented by a much bigger classmate. The bullying went on for days until, resolved not to let himself be intimidated, Ronnie used his fists and managed to knock down this boy who seemed to be a lot stronger and abused it. For Lee, people who exploited animals were like the bully he remembered from his childhood. ${ }^{44}$ Many of the militants involved in ALF's commando operations against laboratories were similarly prolonging sentiments of justice and pride going back to childhood experiences of revolt against abuses of power. In other words, the desire for autonomy that is alleged to be typical of socio-cultural specialists is not, in itself, 
sufficient to explain the satisfaction that anti-experimentalists may find in the emotional register of exposure so characteristic of their cause. Certain early sensibilities, rooted in their personal histories, turn out to be much more decisive, insofar as such experiences led them to see animal protection as an ideal way to create self-esteem. This self-esteem is all the greater because it began with the overcoming of fear and timidity resulting from an initial selfidentification as one of the weak. Here, a militant who, at the age of twelve, joined a club affiliated to the Ligue Française contre la Vivisection explains how animal protection taught him how to assert himself:

\footnotetext{
Actually I had rather a difficult adolescence ... Because ... Once again, it's personal, but I'll tell you... I didn't have all that many friends and I didn't have all that much self-confidence either ... And then my life wasn't all that easy because I'm quite a mild sort of person ... And if they hit me, at that time anyway, I didn't hit back. And actually I think I really put a lot of myself into the animal cause because that helped me regain a bit of self-confidence. My life was a bit of a muddle ... The fledgling animal protection society I founded later on. ${ }^{45}$
}

Without engaging in any psychologism, it is worth stressing that the sensibilities which distinguish the militants of the late twentieth and early twenty-first century from their predecessors arise not only from different social status, but also from the many changes in norms and representations that brought them into contact with the affective experiences that shaped them. These included a lowering of the tolerance threshold for violence; a weakening of hierarchical distinctions; the increasing popularity of pet animals; an increased propensity to identify with other species thanks to cartoons and animal documentaries, etc. This list cannot, of course, be exhaustive, because the crucial fact is that sociological explanations of commitment to the cause must be multi-factorial, leaving room for the description of idiosyncrasies in individual biographies which led the individuals concerned into protesting against the abuse of animal experiments.

Far from aiming to probe the full complexity of the history of protest movements against scientific cruelty, this article has pursued different complementary objectives. First, it has shown why it is important to study the emotions and sensibilities that underlie the protest movements. Secondly, it has, making use of the concept of sensitising devices, highlighted the fact that mobilising support is not a simple matter of exploiting discourse, but rather operates by provoking affective reactions in the body. Thirdly, it has stressed the importance of the analytical distinctions necessary to empirically identify various types of affective states which call for epistemological regimes that are both distinct and complementary. Finally, it has stressed - if it still needs stressing - that sociological research cannot do without the invaluable insights furnished by a historical perspective. A study of historical contrasts, however brief, is vital if we are to understand how far sensibilities and emotions - sometimes hastily attributed to allegedly invariable psychological mechanisms - depend on shifting socio-historical contexts whose effects are not always apparent to the individuals being studied. In other words, examining the social shaping and historical evolution of emotions is the best way to recognise some intrinsic requirements of the social sciences. Certainly we need to reconstruct the subjective perceptions of individuals, including their affective dimensions. Nonetheless, this posture of understanding [posture compréhensive] should not detract historical or sociological research from the fundamental principle of non- 
consciousness which holds that explanations of social life cannot be confined to the concepts of those who participate in it but requires multiple viewpoints and changes of focus developed in the course of research. ${ }^{46}$

${ }^{1}$ Between 2005 and 2011 I arranged 68 interviews with militants representing 34 separate organisations. Thirty-
five of these interviews were conducted by me; the rest by a team of four PhD students and a postdoctoral
researcher in political science, Blancaneaux Romain, Emperador Badimon Montserrat, Franquemagne Gael,
Kumeda Maryna, Lejeune Caroline, Renou Gildas.
2 James M. Jasper, 'The Emotions of Protest: Affective and Reactive Emotions in and around Social
Movements', Sociological Forum, 13, (1998), 397-424, 'Emotions and Social Movements: Twenty Years of
Theory and Research', Annual Review of Sociology, 37 (2011), 285-303; Jeff Goodwin, James M. Jasper and
Francesca Polletta, ed., Passionate Politics. Emotions and Social Movements (Chicago: The University of
Chicago Press, 2001); David Snow, Ron Aminzade and Doug McAdam, 'Emotions and Contentious Politics', in
Ron Aminzade et al., Silence and Voice in the Study of Contentious Politics (Cambridge: Cambridge University
Press, 2001); Isabelle Sommier, 'Les états affectifs ou la dimension émotionnelle des mouvements sociaux', in
Eric Agrikolianski, Olivier Fillieule and Isabelle Sommier, Penser les mouvements sociaux: Conflits sociaux et
contestations dans les sociétés contemporaines (Paris: La Découverte, 2010). See also the introduction of this contestation
theme issue.

${ }^{3}$ Christophe Traïni and Johanna Siméant, 'Pourquoi et comment sensibiliser à la cause?', in Christophe Traïni, ed., Emotions... mobilisation! (Paris: Presses de Science Po, 2009), 13.

${ }^{4}$ The need to consider emotions as practices stemming from bodily dispositions conditioned by a social context is stressed by Monique Scheer in an article drawing on the sociology of Pierre Bourdieu: 'Are Emotions a Kind of Practice (and Is That What Makes Them Have a History)? A Bourdieuan Approach to Understanding Emotion', History and Theory, 51, 2 (2012), 193-220. My approach, though very similar to Scheer's, does not assume that Bourdieu's theoretical biases are a sine qua non for the sociology of dispositions. On this see Bernard Lahire, 'De la théorie de l'habitus à une sociologie psychologique', in B. Lahire B. (ed.), Le Travail sociologique de Pierre Bourdieu. Dettes et critiques (Paris: La Découverte, 1999).

${ }^{5}$ Christophe Traini, La cause animale (1820-1980). Essai de sociologie historique (Paris: Presses Universitaires de France, 2011).

${ }^{6}$ William M. Reddy, 'Against Constructionism: The Historical Ethnography of Emotions', Current Anthropology, 38, 3 (1997), 327-351; The Navigation of Feeling: A Framework for the History of Emotions (Cambridge and New York: Cambridge University Press, 2001).

${ }^{7}$ Reddy, 'Against Constructionism'.

${ }^{8}$ Deborah B. Gould, Moving Politics: Emotion and ACT UP's Fight Against AIDS (Chicago: University of Chicago Press, 2009).

${ }^{9}$ Christophe Traini, 'From Feelings to Emotions (and back again). How Does One Become an Animal Rights Militant?', Revue française de science politique - English, 60, 1, (2010), 219-240.

${ }^{10}$ Anthony Giddens, The Constitution of Society: Outline of the Theory of Structuration (Berkeley and Los Angele: University of California Press, 1984).

${ }^{11}$ Carlo Ginzburg, 'Clues: Roots of a Scientific Paradigm', Theory and Society, 7/3 (1979), 273-88.

${ }^{12}$ Howard S. Becker, Outsiders: Studies in the Sociology of Deviance (New York: The Free Press, 1973).

${ }^{13}$ See R.D. French, Antivivisection and Medical Science in Victorian Society (Princeton: Princeton University Press, 1975). Nicolaas A. Rupke, ed., Vivisection in Historical Perspective (London: Croom Helm, 1987). Coral Lansbury, The Old Brown Dog: Women, Workers, and Vivisection in Edwardian England (Madison: University of Wisconsin Press, 1985). Jacqueline Lalouette, 'Vivisection et anti-vivisection en France au XIX ${ }^{\mathfrak{e}}$ siècle', Ethnologie français, XX, 2 (1990), 156-65.

${ }^{14}$ France Power Cobbe was a member of an Anglo-Irish family with a distinguished record of service in tbe British army and the Anglican church, to which it contributed no fewer than five archbishops.

${ }^{15}$ Bulletin de la Société française contre la vivisection, 3 (1885), Bibliothèque Nationale de France (BNF), microfilm M-4960, 52.

${ }^{16}$ Patrizia Guarnieri, 'Moritz Schiff (1823-96): Experimental Physiology and Noble Sentiment in Florence', in

Nicolaas A. Rupke, ed., Vivisection in Historical Perspective (London, Croom Helm, 1987), 105-24.

${ }^{17}$ Henri Kleffler, Les Missions 'humanitaires' des dames anglaises sur le continent: la vivisection, son utilité, sa morale, réponse à la campagne antivivisectionniste de Mme le Dr Anna Kingsford (Geneva: H. Georg, 1883.)

${ }_{18}$ Ulrich Tröhler and Andréas-Holger Maehle, 'Anti-vivisection in Nineteenth-Century Germany and

Switzerland: Motives and Models', in Rupke, ed., Vivisection in Historical Perspective, 163.

${ }^{19}$ Bulletin de la Société Française contre la Vivisection, 10 (1894), BNF, microfilm M-4960, 37.

${ }^{20}$ Bulletin de la Société Française contre la Vivisection, 4 (1886), BNF, microfilm M-4960, 32. 
${ }^{21}$ Even in France, in 1884, no fewer than seven of the thirty Directors of the Sociéte Française contre la Vivisection were titled individuals. Bulletin de la Société Française contre la Vivisection, 2 (1884), BNF, microfilm M-4960, 52.

${ }^{22}$ Émilie Dardenne, 'France Power Cobbe (1822-1904): militante victorienne. Deux causes un engagement', thèse d'anglais, Université de Rennes-II, 2003, 213.

${ }^{23}$ Bulletin de la Société Française contre la Vivisection, (4), 1886, BNF, microfilm M-4960, 23.

${ }^{24}$ James Turner, Reckoning with the Beast. Animals, Pain and Humanity in the Victorian Mind (Baltimore: The Johns Hopkins University Press, 1980), 101.

${ }^{25}$ Notices and tracts exhorted 'Persons who have lost a dog, cat or any other domestic animal [...] to report the loss in writing, with a very detailed description, to [...] the headquarters of the Société Française contre la Vivisection'. Bulletin de la Société Française contre la Vivisection, 9 (1892), BNF, microfilm M-4960, 34.

${ }^{26}$ Coral Lansbury, 'Gynaecology, Pornography and the Anti-Vivisection Movement', Victorian Studies, 28, (1985), 413-37.

${ }^{27}$ On the importance of taking interpretive risks, and the difference between this and over-interpretation, see Jean-Pierre Olivier de Sardan, 'La violence faite aux données', Enquête, 3 (1996), 31-59.

${ }^{28}$ Craig Buettinger, 'Antivivisection and the Charge of Zoophil-psychosis in the Early Twentieth Century', The Historian, 15/2 (1993), 277-89.

${ }^{29}$ Traïni, La cause animale, 177.

${ }^{30}$ James M. Jasper and Dorothy Nelkin, The Animal Rights Crusade: The Growth of a Moral Protest (New York, The Free Press, 1992).

${ }^{31}$ www.animalliberationfront.com accessed 15/06/2010.

32 Christophe Traïni, 'Témoigner de l'immersion dans l'horreur. Un dispositif de sensibilisation au service d'une cause militante ', paper read at a conference entitled 'En Immersion', Centre de Recherches sur l'Action

Politique en Europe (CRAPE), Institut d'Etudes Politiques de Rennes, November 2013.

${ }^{33}$ Hanspeter Kriesi, 'New Social Movements and the New Class in the Netherlands', The American Journal of Sociology, 94 /5 (1989), 1078-116.

${ }^{34}$ Jacques M. Kalmar, Tortures sans frontière. Torture des hommes, torture des animaux. Un seul problème (Saint-Raphaël: Ligue Française contre la Vivisection et l'Expérimentation sur les Animaux, Editions Les bardes, 1985), 4.

${ }^{35}$ Pamphlet by Jacques M. Kalmar, Les transplantation en question (Saint-Raphaël: Ligue Française contre la Vivisection et l'Expérimentation sur les Animaux, 1991), 17.

${ }^{36}$ Peter Singer, Animal Liberation (New York: Ecco Press, 2002 edition), 84.

${ }^{37}$ Interview 47, female, age 45, militant with the association Contre L'Exploitation Des Animaux, Paris, August 2010.

${ }^{38}$ Interview 61, male, age 37, militant with the association Veg'nord, Lille, July 2010.

${ }^{39}$ In the nineteenth century, these two types of preoccupation were linked to quite different types of activism and to different emotional registers. See my La cause animale.

${ }^{40}$ On dietary conversions among animal protection militants see Christophe Traïni, 'Between Disgust and Moral Indignation. The Socio-genesis of a Militant Practice', Revue Française de Science Politique - English, 62-4, (2012), 1-21

${ }^{41}$ Eric Agrikoliansky, 'Carrières militantes, et vocation à la morale: les militants de la Ligue des droits de l'homme dans les années 1980', Revue Française de Science politique, 51/ 1 (2001), 27-46.

${ }^{42}$ Interview 51, female, age 33, militant with Agir Contre la Torture des Animaux, Bordeaux, May 2010.

${ }^{43}$ Interview 46, female, age 35, militant with the Coalition Anti Vivisection, Paris, August 2010.

${ }^{44}$ From an interview reported by Sabrina Tonutti, Diritti animali: storia e anthropologia di un movimento

(Udine: Forum, 2007), p. 116.

${ }^{45}$ Interview 20, male, age 34, militant in Protection des Animaux de Ferme, Paris, June 2008.

${ }^{46}$ Pierre Bourdieu, Jean-Claude Chamboredon and Jean-Claude Passeron, Le métier de sociologue: préalables épistémologiques (Paris: Mouton \& EHESS, 1983), 30. 